ZOOLOGIA 31 (1): 20-27, February, 2014

http://dx.doi.org/10.1590/S1984-46702014000100003

\title{
Relative growth, sexual dimorphism and morphometric maturity of Trichodactylus fluviatilis (Decapoda: Brachyura: Trichodactylidae) from Santa Terezinha, Bahia, Brazil
}

\author{
Tiago Rozário da Silva ${ }^{1,3}$, Sérgio Schwarz da Rocha ${ }^{2} \&$ Eraldo Medeiros Costa Neto
}

\author{
${ }^{1}$ Departamento de Ciências Biológicas, Universidade Estadual de Feira de Santana. Avenida Transnordestina, Novo Horizonte, \\ 44036-900 Feira de Santana, BA, Brazil.E-mail: apingorasilva@hotmail.com; eraldont@hotmail.com \\ ${ }^{2}$ Laboratório de Bioecologia de Crustáceos, Centro de Ciências Agrárias, Ambientais e Biológicas, Universidade Federal do \\ Recôncavo da Bahia. Rua Rui Barbosa 710,44380-000 Cruz das Almas, BA, Brazil. E-mail: ssrocha@ufrb.edu.br \\ ${ }^{3}$ Corresponding author. E-mail: apingorasilva@hotmail.com
}

\begin{abstract}
Freshwater crabs are important elements in the aquatic biota of brooks, rivers, lakes and ponds, from both ecological and the socio-economic aspects. Trichodactylidae comprises 51 endemic species from the Neotropical region. Among all the species of this family, Trichodactylus fluviatilis Latreille, 1828 has the widest geographic distribution throughout Brazil. Despite that, there are few published contributions on the biology of this species. The present study investigated the following aspects of $T$. fluviatilis: relative growth, mean size at onset of morphometric maturity, sexual dimorphism, laterality and heterochely. Specimens were collected monthly from September 2010 through August 2011, from the Velha Eugênia Brook, municipality of Santa Teresinha, State of Bahia. Carapace width (CW), carapace length $(\mathrm{CL})$, major cheliped length $(\mathrm{MaCL})$ and minor cheliped length $(\mathrm{MiCL})$, major cheliped height $(\mathrm{MaCH})$ and minor cheliped height $(\mathrm{MiCH})$, and width of the fifth abdominal segment (5AB) were measured to evaluate the presence of sexual dimorphism; the major difference between the sexes was in the CW vs. 5AB ratio. Heterochely was observed in males and females, with the right cheliped larger than the left in $89 \%$ of males and $81 \%$ of females. Crab size at the onset of morphometric maturity (= puberty molt) was estimated based on the ratio between $\mathrm{CL}$, cheliped dimensions, $5 A B$ and $C W$ (independent variable). Females were larger than males when they reached morphometric maturity in all studied relations. We recommend the use of chelipeds and abdominal width relationships to estimate the size at the morphometric maturity in males and females, respectively.
\end{abstract}

KEY WORDS. Allometry; chelipeds; crabs; maturity size; Serra da Jibóia.

Trichodactylidae comprises 51 endemic species from the Neotropical region. All members of the family are considered "true freshwater" crabs (sensu Yво et al. 2008), because they have direct development and complete their entire life cycle independently of the marine environment (MüLler, 1892, Yео et al. 2008). Trichodactylus Latreille, 1828 includes 11 valid species, nine of which have been reported from Brazil (MAGALHÃES 2003). Most trichodactylid crabs that occur in Brazil inhabit coastal-plain rivers at altitudes up to 300 m (MAGALHÃEs 2003), with some specimens collected at altitudes up to $960 \mathrm{~m}$ (GOMIDES et al. 2009, Mossolin \& Mantelatto 2008, Rocha \& Bueno 2004, 2011).

Trichodactylus fluviatilis Latreille, 1828 has a wide geographic distribution along the Brazilian coast, from the state of Pernambuco to the state of Rio Grande do Sul (Magalhães 2003). Despite this wide range, little is known about the biology of the species (Mansur et al. 2005). Alarcon et al. (2002) investigated the structure of a population from Ubatuba, São
Paulo, in which sex ratio was 1:1, and females were larger than males. According to these authors, ovigerous females of $T$. fluviatilis have cryptic behavior, and were therefore absent from their sample. Later, CosTA-NeTo (2007) studied some etnocarcinological aspects of the species in the state of Bahia. In addition, studies have examined the association of $T$. fluviatilis with Temnocephala Blanchard, 1849 flatworms (Амато et al. 2005, 2006) and also the use of this species as a bioindicator of some metals, including aluminum, manganese, cadmium and lead (Chagas et al. 2009, Franchi et al. 2011).

Recently, Lima et al. (2012) reported on the allometric growth and average size of $T$. fluviatilis crabs from southeastern Brazil at the onset of morphometric maturity. Published studies on relative growth in brachyuran crabs often find a relationship between allometric growth and morphometric maturity, since the puberty molt is usually marked by a significant change in the allometric growth rate of some body structures such as the carapace, chela and abdomen (HARTNOLL 1978). 
Considering the ecological importance of freshwater crabs and the continuous degradation of their habitats, it is important to study the biological aspects of these crustaceans, aiming the conservation and sustainable use of this natural resource. This study investigated the relative growth and average size of $T$. fluviatilis crabs at the onset of morphometric maturity, in order to provide information that could contribute to efforts to protect this species in the state of Bahia, Brazil.

\section{MATERIAL AND METHODS}

Specimens were sampled monthly, from September 2010 through August 2011, in a 100-m long section of Velha Eugênia Brook (12 $\left.50^{\prime} 42.9^{\prime \prime} S, 39^{\circ} 29^{\prime} 46.4^{\prime \prime W}\right)$, Pedra Branca Village, Santa Terezinha Municipality, Bahia, Brazil (Fig. 1). The sampling site had a sandy substrate, with slow water flow, and the water depth rarely exceeded $50 \mathrm{~cm}$. In backwaters in some areas of the brook, large amounts of organic matter (mainly leaf litter) accumulated. Some partially submerged vegetation was present along the stream banks, and impacts caused by humans and farm animals were evident.

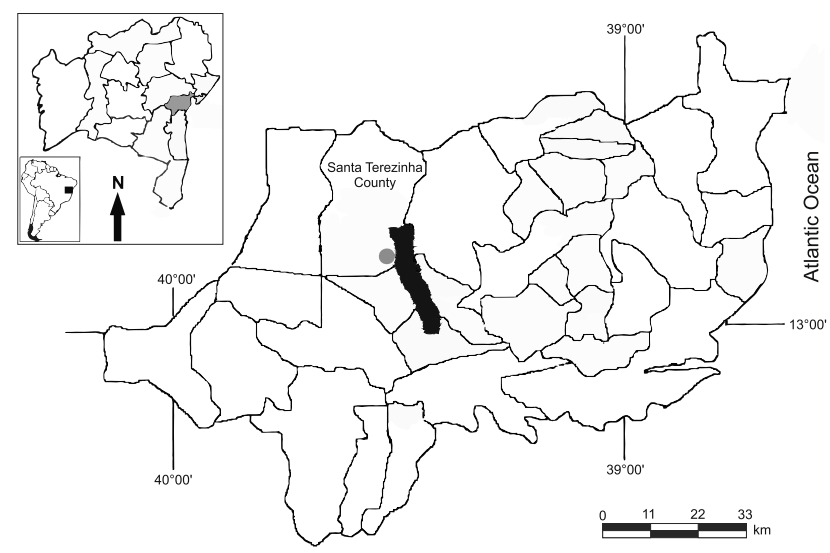

Figure 1. Map of southeast Bahia. Black area, Serra da Jibóia; gray spot, sampling site at Pedra Branca Village.

Trichodactylids were collected during daytime, with the aid of sieves (diameter $50 \mathrm{~cm}$, mesh $0.5 \mathrm{~mm}$ ). Crabs were sexed according to the location of the genital pores, external morphology of the abdomen, and the presence of developed pleopods (females) or two pairs of gonopods (males).

Body dimensions measured were: carapace width (CW), carapace length (CL), major claw propodus length (MaCL), major claw height $(\mathrm{MaCH})$, minor claw propodus length (MiCL), minor claw height $(\mathrm{MiCH})$, and fifth abdomen segment width $(5 \mathrm{AB})$. All measurements were taken to the nearest $0.01 \mathrm{~mm}$ with the aid of a digital caliper, and were used in the relative growth analysis and to estimate the average size at the onset of morphometric maturity.

Except for a few animals fixed as voucher material (INPA 1398), all other specimens caught were returned alive to the sampling site after their measurements were taken.

Data from all measurements taken were converted to the linear form by means of natural logarithm transformation. Logtransformed values of carapace width $(\operatorname{lnCW})$ were used as the independent variable, and all other body dimensions [Ln (claw dimension); $\ln (\mathrm{CL})$; and $\ln (5 \mathrm{AB})]$ were considered as dependent variables. Data were subjected to successive linear regression analysis, and data with corresponding absolute values of the standardized residuals higher than 2.57 ( $p<0.01)$ were considered outliers and excluded from the analysis. Then, each data group from the regression analysis was subjected to non-hierarchical k-means clustering, to separate the data set into juveniles and adults. Discriminant analysis was used to re-allocate any misclassified data. All statistical analyses were performed with the PAST - Paleontological Statistics Software (version 2.14) computer program (HAMmer et al. 2001). Finally, the equations obtained from each linear regression (lny $=\operatorname{lna}+\mathrm{bx}$ ) were tested statistically using covariance analysis (ANOVA), and all of them showed high significance levels (ZAR 1996).

The state of allometry of each body dimension was determined by testing the slope and elevation of each linear equation obtained from regression analysis, using Student's $t$ test (ZAR 1996). Whenever the " $b$ " value was statistically equal to 1 $\left(\mathrm{H}_{0}\right)$ growth was considered isometric; when " $\mathrm{b}$ " was different from $1\left(\mathrm{H}^{\prime}\right)$ growth was considered positively $(\mathrm{b}>1)$ or negatively allometric $(\mathrm{b}<1)$ (Hartnoll 1978, 1982, MarTinez-MaYén et al. 2000, Bueno \& SHimizu 2009). Student's $t$ test was also applied to compare the parameters of allometric equations of juveniles and adults, in both sexes.

Mean size at the onset of morphometric maturity in each sex was calculated only for dimensions in which significant differences were detected by Student's t test when comparing the allometric equations from data groups for juveniles and adults. As performed by Bueno \& Shimizu (2009), the size of morphometric maturity (L50) was calculated from the function $\mathrm{y}=1 / 1+\mathrm{e}^{(-\mathrm{a}-\mathrm{bx})}(\mathrm{y}=$ proportion of adults; $\mathrm{x}=$ carapace width size class), with the software CurveExpert, version 1.3 (Hyams 2001).

Handedness was verified in adult males and females separately with the Yates corrected goodness-of-fit chi-square test. The heterochely of the claws was tested with the non-parametric Wilcoxon test for paired samples (ZAR 1996).

Sexual dimorphism was determined based on body (CW and $5 \mathrm{AB}$ ) and claw dimensions of adult specimens (Mossolin \& Bueno 2003, Bueno \& Shimizu 2009). Carapace width of males and females was compared with the non-parametric MannWhitney test because data for both males $(\mathrm{W}=0.88, \mathrm{p}<0.001$ ) and females ( $\mathrm{W}=0.89, \mathrm{p}<0.01$ ) showed a non-normal distribution (ZAR 1996). Fifth abdominal segment and claw dimen- 
sions were compared with Student's $t$ test (ZAR 1996), used to compare regression parameters between adult specimens.

\section{RESULTS}

Of the total of 623 specimens of T. fluviatilis sampled, 212 were juveniles, 220 males and 191 females. Carapace width ranged from 5.39 to $30.42 \mathrm{~mm}$ (Mean \pm S.D. $=11.46 \pm 4.09 \mathrm{~mm}$ ) in males and from 5.50 to $28.97 \mathrm{~mm}$ (Mean \pm S.D. $=13.10 \pm 5.04$ $\mathrm{mm}$ ) in females. Although males attained the largest carapace width recorded, the mean size of females exceeded males by $1.64 \mathrm{~mm}$ and the Student's $t$ test detected a significant difference in the mean size of the sexes $(t=3.55 ; \mathrm{p}<0.001)$.

\section{Relative Growth}

All linear regression parameters obtained for each data set are shown in Table I. Juveniles of both sexes showed the same state of allometry in the linear regression equations for carapace and claw dimensions. However, the growth of the fifth abdominal segment width was negatively allometric in juvenile males and positively allometric in juvenile females.
Adult males showed positive allometry for all body dimensions, except for the fifth abdominal segment, which showed isometric growth. Adult females showed positive allometry in most of the claw dimensions, except for the minor cheliped height, which showed isometric growth. Unlike males, females showed positive allometry for the fifth abdominal segment and negative allometry for the carapace length.

Comparison between juveniles and adults indicated significant differences in all linear equations obtained from regression analyses, except for the $\mathrm{MiCH}$ (juvenile males vs. adult males) and MiCL (juvenile females vs. adult females) growth relationships (Table II). Therefore, different growth patterns were found between the two life phases that mark the transition from immature to adult.

\section{Sexual dimorphism}

Females were larger than males (Mann-Whitney test: $\mathrm{U}=$ $16820, \mathrm{p}=0.0005)$. Except for the $\mathrm{MiCH}$ relationship, all other dimensions were strongly sexually dimorphic (Table III). The most pronounced sexual dimorphism was detected in the fifth abdominal segment (Fig. 2 and Table I).

Table I. Trichodactylus fluviatilis. Linear regression parameters and equations, and the state of allometry corresponding to each regression.

\begin{tabular}{|c|c|c|c|c|c|}
\hline Category & Relationship ${ }^{1}$ & $\mathrm{n}$ & $\begin{array}{l}\text { Linear regression equation and } \\
\text { coeficient of determinance }\left(r^{2}\right)\end{array}$ & $\begin{array}{l}\text { Student's } \mathrm{t} \text { test for } \\
\text { allometry }\left(\mathrm{H}_{0}: \mathrm{b}=1\right)\end{array}$ & State of allometry ${ }^{2}$ \\
\hline \multirow[t]{6}{*}{ Young Males } & CL vs. CW & 203 & $y=0.9694 x+0.0162 ; r^{2}=0.96$ & $\mathrm{t}=2.31 ; \mathrm{p}<0.05$ & $(-)$ \\
\hline & $\mathrm{MaCL}$ vs. CW & 119 & $y=0.9812 x-0.6415 ; r^{2}=0.81$ & $\mathrm{t}=0.43 ; \mathrm{p}>0.50$ & (0) \\
\hline & $\mathrm{MaCH}$ vs. $\mathrm{CW}$ & 117 & $y=1.1529 x-1.6983 ; r^{2}=0.94$ & $\mathrm{t}=5.55 ; \mathrm{p}<0.001$ & $(+)$ \\
\hline & MiCL vs. CW & 120 & $y=0.9777 x-0.7432 ; r^{2}=0.78$ & $t=0.46 ; p>0.50$ & (0) \\
\hline & $\mathrm{MiCH}$ vs. $\mathrm{CW}$ & 114 & $y=1.0407 x-1.6321 ; r^{2}=0.88$ & $t=1.10 ; p>0.20$ & (0) \\
\hline & $5 A B$ vs. $C W$ & 121 & $y=0.865 x-0.9985 ; r^{2}=0.66$ & $\mathrm{t}=109.67 ; \mathrm{p}<0.001$ & $(-)$ \\
\hline \multirow[t]{6}{*}{ Adult Males } & $\mathrm{CL}$ vs. $\mathrm{CW}$ & 179 & $y=1.0482 x-0.0225 ; r^{2}=0.99$ & $\mathrm{t}=7.47 ; \mathrm{p}<0.001$ & $(+)$ \\
\hline & MaCL vs. CW & 162 & $y=1.2889 x-1.2718 ; r^{2}=0.90$ & $\mathrm{t}=8.54 ; \mathrm{p}<0.001$ & $(+)$ \\
\hline & $\mathrm{MaCH}$ vs. CW & 145 & $y=1.4655 x-2.3886 ; r^{2}=0.97$ & $\mathrm{t}=21.57 ; \mathrm{p}<0.001$ & $(+)$ \\
\hline & MiCL vs. CW & 163 & $y=1.0747 x-0.8824 ; r^{2}=0.91$ & $\mathrm{t}=2.86 ; \mathrm{p}<0.005$ & $(+)$ \\
\hline & $\mathrm{MiCH}$ vs. $\mathrm{CW}$ & 159 & $y=1.0484 x-1.6369 ; r^{2}=0.95$ & $\mathrm{t}=2.63 ; \mathrm{p}<0.01$ & $(+)$ \\
\hline & $5 A B$ vs. CW & 69 & $y=1.0335 x-1.2606 ; r^{2}=0.90$ & $\mathrm{t}=0.79 ; 0.20<\mathrm{p}<0.50$ & $(0)$ \\
\hline \multirow[t]{6}{*}{ Young Females } & $\mathrm{CL}$ vs. $\mathrm{CW}$ & 199 & $y=0.9403 x+0.0537 ; r^{2}=0.99$ & $\mathrm{t}=7.42 ; \mathrm{p}<0.001$ & $(-)$ \\
\hline & MaCL vs. CW & 139 & $y=1.0068 x-0.6821 ; r^{2}=0.89$ & $\mathrm{t}=0.22 ; \mathrm{p}>0.50$ & (0) \\
\hline & $\mathrm{MaCH}$ vs. $\mathrm{CW}$ & 129 & $y=1.1103 x-1.6292 ; r^{2}=0.95$ & $\mathrm{t}=4.85 ; \mathrm{p}<0.001$ & $(+)$ \\
\hline & MiCL vs. CW & 127 & $y=1.0051 x-0.7822 ; r^{2}=0.82$ & $\mathrm{t}=0.12 ; \mathrm{p}>0.50$ & (0) \\
\hline & $\mathrm{MiCH}$ vs. CW & 118 & $y=0.9941 x-1.5538 ; r^{2}=0.90$ & $\mathrm{t}=0.19 ; \mathrm{p}>0.50$ & (0) \\
\hline & $5 \mathrm{AB}$ vs. $\mathrm{CW}$ & 117 & $y=1.3485 x-1.9851 ; r^{2}=0.89$ & $\mathrm{t}=7.91 ; \mathrm{p}<0.001$ & $(+)$ \\
\hline \multirow[t]{6}{*}{ Adult Females } & $\mathrm{CL}$ vs. CW & 172 & $y=0.9722 x-0.0261 ; r^{2}=0.99$ & $\mathrm{t}=5.82 ; \mathrm{p}<0.001$ & $(-)$ \\
\hline & MaCL vs. CW & 116 & $y=1.2184 x-1.1534 ; r^{2}=0.94$ & $\mathrm{t}=7.35 ; \mathrm{p}<0.001$ & $(+)$ \\
\hline & $\mathrm{MaCH}$ vs. CW & 109 & $y=1.2704 x-1.9811 ; r^{2}=0.97$ & $t=11.66 ; p<0.001$ & $(+)$ \\
\hline & MiCL vs. CW & 124 & $y=1.0497 x-0.8521 ; r^{2}=0.94$ & $\mathrm{t}=2.03 ; \mathrm{p}<0.05$ & $(+)$ \\
\hline & $\mathrm{MiCH}$ vs. $\mathrm{CW}$ & 117 & $y=1.0121 x-1.54 ; r^{2}=0.9764$ & $\mathrm{t}=0.83 ; \mathrm{p}<0.50$ & (0) \\
\hline & $5 \mathrm{AB}$ vs. $\mathrm{CW}$ & 57 & $y=1.8019 x-3.1106 ; r^{2}=0.94$ & $\mathrm{t}=12.76 ; \mathrm{p}<0.001$ & $(+)$ \\
\hline
\end{tabular}

${ }^{1} \mathrm{CW}$, carapace width; $\mathrm{CL}$, carapace length; $5 \mathrm{AB}$, width of the fifth abdominal segment; $\mathrm{MaCL}$, major cheliped propodus lenght; MaCH, major cheliped height; $\mathrm{MiCL}$, minor cheliped propodus length; $\mathrm{MiCH}$, minor cheliped height.

2 State of allometry: $(-)$ negatively allometric; $(+)$ positively allometric; $(0)$ isometric. 

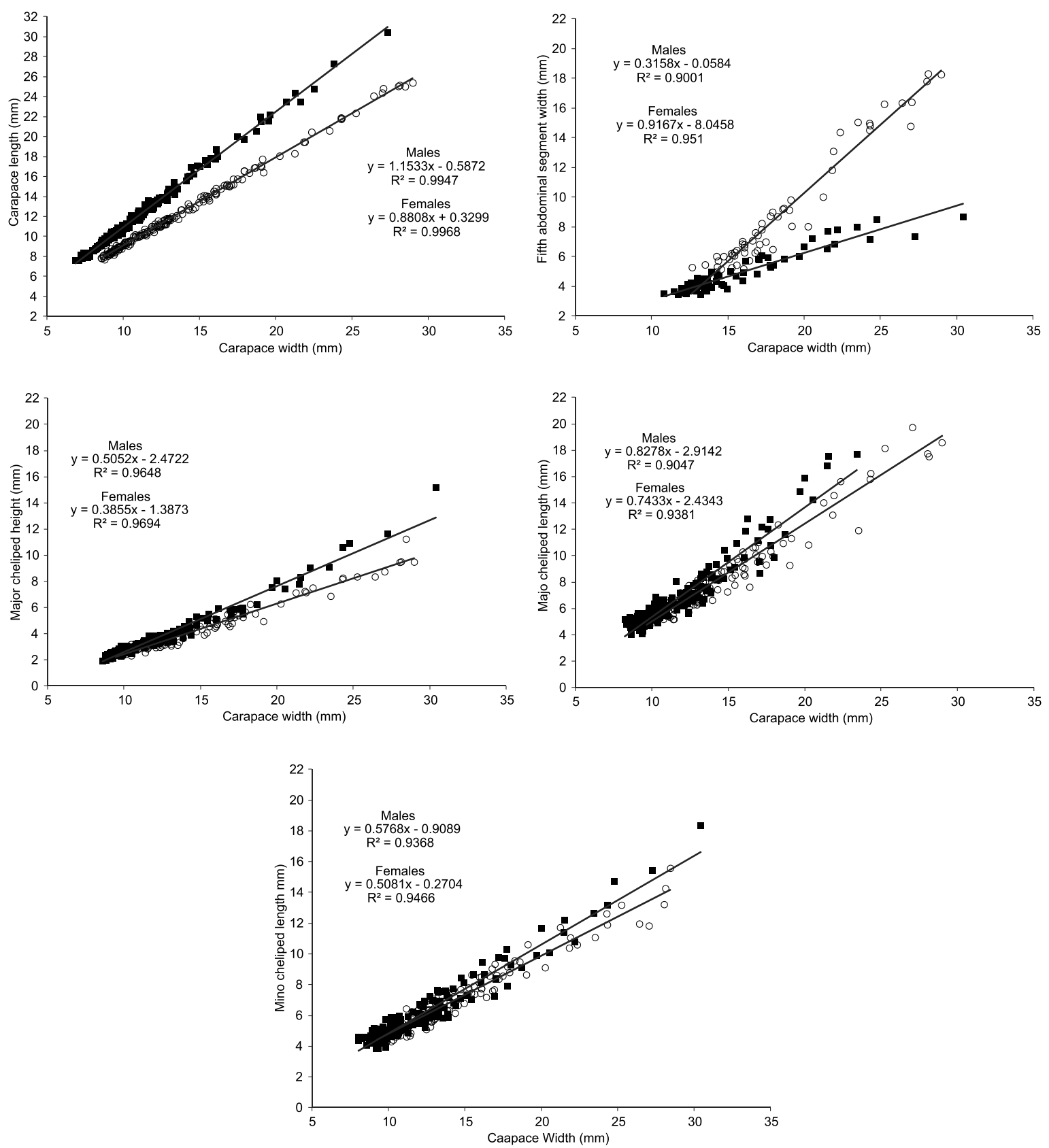

Figure 2. Trichodactylus fluviatilis. Sexual dimorphism in biometric relationships (non-linearized data). Solid quadrat, adult males; empty circle, adult female.

\section{Laterality and Heterochely}

Laterality analysis showed that $89 \%$ of males $\left(\chi^{2}=110.45\right.$, $\mathrm{p}<0.001)$ and $81 \%$ of females $\left(\chi^{2}=60.31, \mathrm{p}<0.001\right)$ showed right-handedness. Males and females of T. fluviatilis are heterochelous, since comparisons of all chela dimensions gave significant results (Wilcoxon test, $\mathrm{p}<0.001$ ).

\section{Morphometric maturity}

The mean sizes of carapace width at the onset of morphometric maturity estimated for each variable are shown in Table IV. For males and females, the maturation size (= puberty molt) could not be estimated from the minor cheliped height and the minor cheliped length relationships, respectively, be- 
Table II. Trichodactylus fluviatilis. Student's t comparisons of linear regression parameters between juvenile and adult life stages. v, degrees of freedom.

\begin{tabular}{|c|c|c|c|}
\hline Life stages & Relationship ${ }^{1}$ & Comparison of slopes & Comparison of elevations \\
\hline \multirow[t]{6}{*}{ Young males vs. Adult males } & $\mathrm{CL}$ vs. CW & $\mathrm{t}=5.24 ; \mathrm{v}=378 ; \mathrm{p}<0.001$ & \\
\hline & $\mathrm{MaCL}$ vs. $\mathrm{CW}$ & $\mathrm{t}=5.56 ; \mathrm{v}=277 ; \mathrm{p}<0.001$ & \\
\hline & $\mathrm{MaCH}$ vs. $\mathrm{CW}$ & $\mathrm{t}=8.80 ; \mathrm{v}=258 ; \mathrm{p}<0.001$ & \\
\hline & MiCL vs. CW & $\mathrm{t}=1.88 ; \mathrm{v}=279 ; \mathrm{p}>0.05$ & $\mathrm{t}=2.79 ; \mathrm{v}=280 ; \mathrm{p}<0.01$ \\
\hline & $\mathrm{MiCH}$ vs. $\mathrm{CW}$ & $\mathrm{t}=0.20 ; \mathrm{v}=269 ; \mathrm{p}>0.50$ & $\mathrm{t}=0.72 ; \mathrm{v}=270 ; \mathrm{p}>0.20$ \\
\hline & $5 A B$ vs. $C W$ & $\mathrm{t}=2.29 ; \mathrm{v}=186 ; \mathrm{p}<0.05$ & \\
\hline \multirow[t]{6}{*}{ Young females vs. Adult females } & CL vs. CW & $\mathrm{t}=3.42 ; \mathrm{v}=367 ; \mathrm{p}<0.001$ & \\
\hline & $\mathrm{MaCL}$ vs. CW & $\mathrm{t}=4.92 ; \mathrm{v}=251 ; \mathrm{p}<0.001$ & \\
\hline & $\mathrm{MaCH}$ vs. CW & $\mathrm{t}=4.93 ; \mathrm{v}=234 ; \mathrm{p}<0.001$ & \\
\hline & $\mathrm{MiCL}$ vs. CW & $\mathrm{t}=0.94 ; \mathrm{v}=247 ; \mathrm{p}>0.20$ & $\mathrm{t}=1.23 ; \mathrm{v}=248 ; \mathrm{p}>0.10$ \\
\hline & $\mathrm{MiCH}$ vs. $\mathrm{CW}$ & $\mathrm{t}=0.55 ; \mathrm{v}=231 ; \mathrm{p}>0.20$ & $\mathrm{t}=3.53 ; \mathrm{v}=232 ; \mathrm{p}<0.001$ \\
\hline & $5 A B$ vs. $C W$ & $\mathrm{t}=5.90 ; \mathrm{v}=170 ; \mathrm{p}<0.001$ & \\
\hline
\end{tabular}

'Legend as in Table I.

Table III. Trichodactylus fluviatilis. Student's t comparisons of linear regression parameters between males and females, to test for sexual dimorphism. $v$, degrees of freedom.

\begin{tabular}{lccccc}
\hline Relationship & $\mathrm{n}$ (males) & $\mathrm{n}$ (females) & Comparison of slopes & Comparison of elevations & Sexual dimorphism \\
\hline CL vs. CW & 179 & 172 & $\mathrm{t}=9.53 ; \mathrm{v}=347 ; \mathrm{p}<0.001$ & & Yes \\
MaCL vs. CW & 162 & 116 & $\mathrm{t}=1.56 ; \mathrm{v}=274 ; \mathrm{p}>0.10$ & $\mathrm{t}=5.05 ; \mathrm{v}=275 ; \mathrm{p}<0.001$ & Yes \\
MaCH vs. CW & 145 & 109 & $\mathrm{t}=6.18 ; \mathrm{v}=250 ; \mathrm{p}<0.001$ & & Yes \\
MiCL vs. CW & 163 & 124 & $\mathrm{t}=0.69 ; \mathrm{v}=283 ; \mathrm{p}>0.20$ & $\mathrm{t}=3.30 ; \mathrm{v}=284 ; \mathrm{p}<0.02$ & Yes \\
MiCH vs. CW & 159 & 117 & $\mathrm{t}=1.51 ; \mathrm{v}=272 ; \mathrm{p}>0.10$ & $\mathrm{t}=0.71 ; \mathrm{v}=273 ; \mathrm{p}>0.20$ & No \\
5AB vs. CW & 69 & 57 & $\mathrm{t}=10.41 ; \mathrm{v}=122 ; \mathrm{p}<0.001$ & & Yes \\
\hline
\end{tabular}

'Legend as in Table I.

cause no significant differences in regression slope and elevation were detected for these data when comparing juveniles and adults (Table II).

The lowest value of maturity size for both sexes (males = $8.35 \mathrm{~mm} \mathrm{CW}$; females $=9.03 \mathrm{~mm} \mathrm{CW}$ ) was obtained from the data set for carapace length. While the largest sizes at the onset of maturity $($ males $=12.63 \mathrm{~mm} \mathrm{CW}$; females $=14.22 \mathrm{~mm}$ $\mathrm{CW}$ ) were obtained from the data set for the fifth abdominal segment (Table IV).

All claw dimensions for which the puberty molt was detected, provided very close estimates of maturation sizes in both sexes. For males, these estimates ranged from 8.99 to 9.12 $\mathrm{mm}$ CW, whereas for females they ranged from 9.69 to 10.15 mm CW (Table IV). As proposed by Bueno \& SHimizu (2009), we suggest the adoption of the mean of the estimated values obtained from the claw dimensions vs. CW relationships, which would represent the size at the onset of morphometric maturity based on these data sets. Thereby, the puberty molt (obtained with the claw dimensions) would occur when specimens attain $\mathrm{CW}=9.05 \mathrm{~mm}$ (males) and $\mathrm{CW}=9.97 \mathrm{~mm}$ (females).
Table IV. Trichodactylus fluviatilis. Average carapace width size $(\mathrm{mm})$ at onset of maturity, regarding the biometric relationships for which significant differences were found between juveniles and adults.

\begin{tabular}{lcc}
\hline \multicolumn{1}{c}{ Relationship $^{1}$} & Male & Female \\
\hline MaCL vs. CW & 8.99 & 10.15 \\
MaCH vs. CW & 9.12 & 10.08 \\
MiCL vs. CW & 9.06 & - \\
MiCH vs. CW & - & 9.69 \\
SAB vs. CW & 12.63 & 14.22 \\
CL vs. CW & 8.35 & 9.03 \\
Mean of the estimated values obtained & $9.05( \pm 0.06)$ & $9.97( \pm 0.25)$ \\
with the claws dimensions &
\end{tabular}

'Legend as inTtable I.

\section{DISCUSSION}

AlarCon et al. (2002) found a population of T. fluviatilis in Ubatuba, São Paulo in which the mean carapace width was greater in females than males. On the other hand, ZimMERMAnN 
et al. (2009) found that males of Trichodactylus panoplus von Martens, 1869 were larger than females, whereas VenÂNCIO \& LEME (2010) and Lima et al. (2012) found similar sizes for males and females in populations of Trichodactylus petropolitanus (Goeldi, 1886) from Caçapava, São Paulo, and T. fluviatilis from Ubatuba, respectively.

Within the Brachyura, males are usually larger than females. This pattern is frequently related to the investment in reproduction over growth by females (HARTNOLL 1982, 1985, TAdDei \& Herrera 2010). Therefore, most crab species are sexually dimorphic in size, with males larger and with larger structures than females ( $\mathrm{N}_{\mathrm{G}}$ et al. 2008).

Males of $T$. fluviatilis crabs from Velha Eugênia brook (present study) grew proportionally more in carapace length than in carapace width (positive allometry), while females showed an opposite growth pattern (negative allometry) (Fig. 2, Table I). With this growth pattern, females from the Velha Eugênia Brook attain a larger CW than males because males grow proportionally more in carapace length. Figure 2 shows that males started investing more energy than females in growing the chelipeds (over CW) when they attained approximately $20 \mathrm{~mm} \mathrm{CW}$. This growth pattern could also affect the mean value of $\mathrm{CW}$ calculated for males, since they would direct more energy to chelae growth than to carapace width.

Chelipeds are often used by males in agonistic behaviors and/or courtship and to protect females during copulation and spawning (Crane 1975, Gherardi \& Micheli 1989, Branco 1993, Masunari \& Dissenha 2005). Therefore, males with more robust chelipeds are better equipped to win the inter-male competition, and are more likely to be selected by their female counterparts (Mariappan et al. 2000, QUReshi \& SAHer 2011). On the other hand, brachyuran females with direct development, for instance $T$. fluviatilis, invest a significant amount of energy in abdominal growth, since this body part is used as an incubating chamber for eggs and newly hatched young (see HARTNOLL 1974, Vogt 2013) (Fig. 2). In males, there is no need for the abdomen to grow faster than the carapace, since it only has the reproductive function of protecting the gonopods (DANIELS 2001, Castiglioni \& Negreiros-Franzoso 2004).

In the present study, the biometric relationships in juveniles of both sexes were mostly isometric, whereas in adults they were mostly positively allometric (Table I). Similar results were found by Lima et al. (2012) for the same species studied at Ubatuba, São Paulo. According to HarTnoll (1982), brachyurans are usually strongly allometric in adulthood. Among all variables investigated, the length and height of the major cheliped in adult males and the fifth abdominal segment in adult females showed the highest coefficient of allometric growth (Table I). These results are consistent with the relative growth pattern observed in brachyurans (HARTNOLL 1974), and reveal the differences in allocation of resources (energy) between males and females. Females divert energy to abdominal growth, while males prioritize cheliped growth, as discussed above.
According to SCALICI \& GHERARDI (2008), in brachyurans, right-handedness is usually the most common condition. This condition was also recorded for males and females of $T$. fluviatilis from Brazilian populations (Lima et al. 2012, present study). Similar patterns have been recorded for freshwater crabs of the families Potamidae and Potamonautidae (Gherardi \& Micheli 1989, Daniels 2001) and some marine taxa (see table II in Mariappan et al. 2000 for review).

In many decapod crustaceans, the right and left chelae are differentiated morphologically into crusher and cutter, making them heterochelous and sexually dimorphic (MARIAPPAN et al. 2000). Generally, the major cheliped is associated with defense, reproduction and crushing of shells, whereas the minor cheliped is used for feeding and cleaning parts of the body (Levinton et al. 1995, Daniels 2001).

Like most freshwater crabs, trichodactylid species are omnivorous (Magalhães 2003, Yeo et al. 2008, Cumberlidge et al. 2009, Zimmermann et al. 2009). According to Daniels (2001), in freshwater crabs such as T. fluvialitis, the major claw may play a less significant role during feeding, since they are either detritivores, or feeding generalists. Therefore, sexual selection is probably the reason why males of freshwater crabs develop a major cheliped that can be used in courtship, agonistic behaviors, and defense of home territory (STEIN 1976, MARIAPPAN et al. 2000, Daniels 2001). On the other hand, the major cheliped of females may act as a signal of sexual vitality and reproductive vigor to males, allowing females to be more successful at mating and have a better chance of defending the developing young (since they show direct development) against predators (DANIELS 2001).

In crustaceans, some aspects such as gonadal development, presence of ovigerous females, and morphometric data are used to calculate the mean size at the onset of maturity. In the present study, the mean size at the onset of morphometric maturity calculated from the fifth abdominal segment data set (male: $12.63 \mathrm{~mm}$; female: $14.22 \mathrm{~mm}$ ) were quite different from those calculated from the cheliped data set (male: $9.05 \mathrm{~mm}$; female: $9.97 \mathrm{~mm}$ ). Considering how important cheliped size is for the reproductive success of males, and abdomen width for females, as discussed above, we recommend the use of chelipeds and abdominal width relationships to estimate the size at morphometric maturity in males and females, respectively. In the case of $T$. fluviatilis, females were larger than males when they attained morphometric maturity (Table IV).

The size at first maturity was also greater in females than in males, in studies conducted by Сово (2006), Сово \& Alves (2009), and Hartnoll (2009). Delayed maturity could allow females of $T$. fluviatilis to live longer, grow larger, and therefore have higher fecundity (RAmirez-Llodra 2002). Furthermore, the size at onset of maturity depends on exogenous factors, such as temperature and/or food availability. Therefore, it is not a fixed character and may vary in different populations of the same species (HARTNOLl 1978). 
Considering that specimens of $T$. fluviatilis are commonly collected by the residents of Pedra Branca Village for medicinal purposes and food (CоsтA Neто 2007), the results presented here are important to establish a minimum catch size that would contribute to the sustainable use and conservation of this species in the state of Bahia.

\section{ACKNOWLEDGMENTS}

The authors express their sincere gratitude to CAPES (Coordenação de Aperfeiçoamento de Pessoal de Nível Superior) for providing financial support (PROAP) and a research grant (740766) to one of us (TRS), and to the State University of Feira de Santana for providing all laboratory facilities. Finally, thank you to Janet W. Reid for her help in the English revision.

\section{LITERATURE CITED}

Alarcon, D.T.; M.H. Leme \& V.J. Сово. 2002. Population structure of the freshwater crab Trichodactylus fluviatilis Latreille, 1828 (Decapoda, Trichodactylidae) in Ubatuba, Northern Coast of Sao Paulo, p. 179-182. In: F. Escobar-Briones (Orgs.). Modern approaches to the study of Crustacea. New York, Kluwer Academic, Plenum Publishers, 376p.

Amato, J.F.R.; S.B. Амato \& S.A. Seixas. 2005. Temnocephala lutzi ectosymbiont on two species of Trichodactylus from southern Brazil. Revista Brasileira de Zoologia 22 (4): 1085-1094. doi: 10.1590/S0101-81752005000400038.

Амato, J.F.R.; S.B. Амato \& S.A. Seixas. 2006. A new species of Temnocephala ectosymbiont on Trichodactylus fluviatilis Latreille (Crustacea, Decapoda, Trichodactylidae) from southern Brazil. Revista Brasileira de Zoologia 23 (3): 796806. doi: 10.1590/S0101-81752007000400022.

Branco, J.O. 1993. Aspectos bioecológicos do caranguejo Ucides cordatus (Linnaeus 1763) (Crustacea, Decapoda) do manguezal do Itacorubi, Santa Satarina, BR. Arquivos de Biologia e Tecnologia 36 (1): 133-148.

BuENo, S.L.S \& R.M. SHimizu. 2009. Allometric growth, sexual maturity and adult male chelae dimorphism in Aegla franca (Decapoda: Anomura: Aeglidae). Journal of Crustacean Biology 29 (3): 317-328. doi: 10.1651/07-2973.1.

Castiglioni, D.S.E \& M.L. Negreiros-Fransozo. 2004. Comparative analysis of the relative growth of Uca rapax (Smith) (Crustacea, Ocypodidae) from two mangroves in São Paulo, Brazil. Revista Brasileira de Zoologia 21 (1): 137-144. doi: 10.1590/S0101-81752008000400004.

Chagas, G.C.; A.L. Brossi-Garcia; A.A. Menegário; A.C.S. Pião \& J.S.Govone. 2009. Use of the freshwater crab Trichodactylus fluviatilis to biomonitoring $\mathrm{Al}$ and $\mathrm{Mn}$ contamination in river water. Holos Environment 9 (2): 289-300.

Сово, V.J. 2006. Population biology of the spider crab, Mithraculus forceps (A. Milne-Edwards, 1875) (Majidae, Mithraci- nae) on the southeastern Brazilian coast. Crustaceana 78 (9): 1079-1087.

Сово, V.J \& D.R.F. Alves. 2009. Relative growth and sexual maturity of the spider crab, Mithrax tortugae Rathbun, 1920 (Brachyura, Mithracidae) on a continental island off the southeastern Brazilian coast. Crustaceana 82 (10): 12651273. doi: 10.1163/00112 1609X12481627024490.

Costa-Neto, E.M. 2007. Caranguejo de água-doce, Trichodactylus fluviatilis (Latreille, 1828) (Crustacea, Decapoda, Trichodactylidae), na concepção dos moradores do povoado de Pedra Branca, Bahia, Brazil. Biotemas 20 (1): 59-68.

Crane, J. 1975. Fiddler crabs of the world. Princeton, Princeton University Press, 725p.

Cumberlidge, N.; P.K.L. NG; D.C.J. Yeo; C. Magalhães; M.R. Campos; F. Alvarez; T. Naruse; S.R. Daniels; L.J. Esser; F.Y.K. Attipoe; F.L. Clotilde-Ba; W. Darwall; A. McLvor; J.E.M. Baillie; B. Collen \& M. Ram. 2009. Freshwater crabs and the biodiversity crisis: Importance, threats, status, and conservation challenges. Biological Conservation 142: 1665-1673. doi:10.1016/j.biocon.2009.02.038

Daniels, S.R. 2001. Allometric growth, handedness, and morphological variation in Potamonautes warreni (Calman, 1918) (Decapoda, Brachyura, Potamonautidae) with a redescription of the species. Crustaceana 74 (3): 237-253. doi: $10.1163 / 156854001505488$.

Franchi, M.; A.A. Menegário; A.L. Brossi-Garcia; G.C. Chagas; M.V. SilvV; A.C.S. PIÃo \& J.S. Govone. 2011. Bioconcentration of $\mathrm{Cd}$ and $\mathrm{Pb}$ by the river crab Trichodactylus fluviatilis (Crustacea: Decapoda). Journal of the Brazilian Chemical Society 22 (2): 230-238. doi: 10.1590/S0103-50532011000200007.

GHerardi, F. \& F. Micheli. 1989. Relative growth and population structure of the freshwater crabs, Potamon potamios palestinensis, in the Dead Sea area. Israel Journal of Zoology 36: 133-145.

Gomides, S.C.; I.A. Novelli; A. O. Santos; S.S.S. Brugiolo \& B.M. Sousa. 2009. Novo registro altitudinal de Trichodactylus fluviatilis (Latreille, 1828) (Decapoda, Trichodactylidae) no Brazil. Acta Scientiarum. Biological Sciences 31 (3): 327 330. doi: 10.4025/actascibiolsci.v31i3.785.

Hammer, O.; D.A.T. Harper \& P.D. Ryan. 2001. Past: Palaeontological Statistics Software Package for Education and Data Analysis. Palaeontological Electronica 4 (1): 9p. Available online at: http:// palaeo-electronica.org/2001_1/past/past.pdf [Accessed:03/IV/2012].

HARTNOLL, R.G. 1974. Variation in growth pattern between some secondary sexual characters in crabs (Decapoda, Brachyura). Crustaceana 27 (2): 151-156.

Hartnoll, R.G. 1978. The determination of relative growth in Crustacea. Crustaceana 34: 281-293.

Hartnoll, R.G. 1982. Growth. In: D.E. Bliss (Ed.), p. 111-196. The Biology of Crustacea: Embryology, Morphology and Genetics. New York, Academic Press.

HarTNOLL, R.G. 1985. Growth, sexual maturity and reproductive output, p.101-128. In: A.M. WeNNER (Ed.). Crustacean Issues 3: Factors in adult growth. Boston, Balkema. 
HaRTNOLL, R.G. 2009. Sexual maturity and reproductive strategy of the rock crab Grapsus adscensionis (Osbeck, 1765) (Brachyuara, Grapsidae) on Ascension Island. Crustaceana 82 (3): 275-291 doi: 10.1163/156854009X409090.

Hyams, D. 2001. CurveExpert 1.3: a comprehensive curve fitting package for Windows. Available online at: www.ebicom.net/ ,DHYAMS/CFTP.HTML [Accessed: 03/IV/2012].

Levinton, J.S.; M.L. Judge \& J.P. Kurdziel. 1995. Functional differences between the major and minor claws of fiddler crabs (Uca, family Ocypodidae, Order Decapoda, Subphylum Crustacea): A result of selection or developmental constraint? Journal of Experimental Marine Biology and Ecology 193: 147-160. doi: 10.1016/0022-0981(95)00115-8.

Lima, D.J.M.; V.J. Совo; D.F.R. Alves; S.P. Barros-Alves \& V. Fransozo. 2012. Onset of sexual maturity and relative growth of the freshwater crab Trichodactylus fluviatilis (Trichodactyloidea) in southeastern Brazil. Invertebrate Reproduction \& Development 57 (2): 105-112. doi: 10.1080/07924259.2012.689263.

MagalHÃES, C. 2003. Brachyura: Famílias Pseudothelphusidae e Trichodactylidae, p. 143-197. In: G.A.S. Melo (Ed.). Manual de identificação dos crustáceos decápodos de água doce Brazileiros. São Paulo, Loyola.

Mansur, C.B.; N.J. Hebling \& J.A. Souza. 2005. Crescimento relativo de Dilocarcinus pagei Stimpson, 1861 e Sylviocarcinus austalis Magalhães e Türkay (Crustacea,Decapoda, Trichodactylidae) no Pantanal do Rio Paraguai, Porto Murtinho, Mato Grosso do Sul. Boletim do Instituto de Pesca 31 (2): 103-107.

Mariappan, P.C.; C. Balasundaram \& B. Schmitz. 2000. Decapod crustacean chelipeds: an overview. Journal of Bioscience 25 (3): 301-313.

Martínez-Mayén, M.; R. Román-Contreras; A. Rocha-Ramírez \& S. Chazaro-Olvera. 2000. Relative growth of Atya margaritacea A. Milne-Edwards, 1864 (Decapoda, Atyidae) from the southern Pacific coast of Mexico. Crustaceana 73 (5): 525-534.

Masunari, S. \& N. Dissenha. 2005. Alometria no crescimento de Uca mordax (Smith) (Crustacea, Decapoda, Ocypodidae) na Baía de Guaratuba, Paraná, Brazil. Revista Brasileira de Zoologia 22 (4): 984-990. doi: 10.1590/S0101-81752005000400026.

Mossolin, E.C. \& S.L.S. Bueno. 2003. Relative growth of the second pereiopod in Macrobrachium olfersi (Wiegmann, 1836) (Decapoda, Palaemonidae). Crustaceana 76 (3): 363-376.

Mossolin, E.C. \& F.L. Mantelatto. 2008. Taxonomic and distributional results of a freshwater crab fauna survey (Family Trichodactylidae) on São Sebastião Island (Ilhabela), South Atlantic, Brazil. Acta Limnologica Brasiliensia 20 (2): 125-129.

Muller, F. 1892. Trichodactylus, siri de água doce sem metamorfose. Arquivo do Museu Nacional do Rio de Janeiro 8: 125-133.
NG, P.K.L.; D. GuInot \& P.J.F. Davie. 2008. Systema Brachyurorum: Part 1. An annotated checklist of extant Brachyuran crabs of the world. Raffles Bulletin of Zoology 17: 1-286.

QURESHI, N.A. \& N.U. SAHER. 2011. Relative growth and morphological sexual maturity of Macrophthalmus (venitus) dentipes Lucas, in Guérin-Méneville, 1836 from two mangrove areas of Karachi Coast. Biharean Biologist 5 (1): 56-62.

Ramirez-Llodra, E. 2002. Fecundity and life-history strategies in marine invertebrates. Advances in Marine Biology 43: 87170.

Rocha, S.S. \& S.L.S. BuENo. 2004. Crustáceos decápodes de água doce com ocorrência no Vale do Ribeira de Iguape e rios costeiros adjacentes, São Paulo, Brazil. Revista Brasileira de Zoologia 21 (4): 1001-1010. doi: 10.1590/S0101-817520040004 00038.

Rocha, S.S. \& S.L.S. Bueno. 2011. Extension of the known distribution of Aegla strinatii Türkay, 1972 and a checklist of decapod crustaceans (Aeglidae, Palaemonidae and Trichodactylidae) from the Jacupiranga State Park, South of São Paulo State, Brazil. Nauplius 19 (2): 163-167.

Scalici, M. \& F. Gherardi. 2008. Heterochely and handedness in the river crab, Potamon potamios (Oliver, 1804) (Decapoda, Brachyura). Crustaceana 81: 507-511. doi:10.1163/ 156854008783797525.

Stein, R.A. 1976. Sexual dimorphism in crayfish chelae: functional significance linked to reproductive activities. Canadian Journal of Zoology 54: 220-227.

Taddei, F.G. \& D.R. HerRera. 2010. Crescimento do caranguejo Dilocarcinus pagei na represa Barra Mansa, Mendonça, SP. Boletim do Instituto de Pesca 35 (2): 99-110.

VenÂNCIO, F.A. \& M.H.A. Leme. 2010. The freshwater crab Trichodactylus petropolitanus associated with roots of Hedychium coronarium. Pan-American Journal of Aquatic Sciences 5 (4): 501507.

Vogt, G. 2013. Abbreviation of larval development and extension of brood care as key features of the evolution of freshwater Decapoda. Biological Reviews of the Cambridge Philosophical Society 88 (1): 81-116.

Yeo, D.C.J.; P.K.L. Ng; N. Cumberlidge; C. Magalhães; S.R. Daniels \& M.R. CAmpos. 2008. Global diversity of crabs (Crustacea: Decapoda: Brachyura). In: freshwater. Hydrobiologia 595: 275-286. doi: 10.1007/978-1-4020-8259-7_30

ZAR, J.H. 1996. Biostatistical Analysis. New Jersey, Prentice Hall, $662 \mathrm{p}$.

Zimmermann, B.L; A.W. Aued; S. Machado; D. Manfio; L.P. Scarton \& S. SAntos. 2009. Behavioral repertory of Trichodactylus panoplus (Crustacea: Trichodactylidae) under laboratory conditions. Zoologia 26 (1): 5-11. doi: 10.1590/S198446702009000100002 .

Submitted: 18.VI.2013; Accepted: 22.XI.2013.

Editorial responsibility: Rosana M. da Rocha 